\title{
曲げ試験に基づく引張軟化曲線の推定と計測 DETERMINATION OF TENSION SOFTENING DIAGRAMS OF CONCRETE BY MEANS OF BENDING TESTS
}

\author{
内田裕市* ·六郷恵哲** 小 小柳 洽*** \\ By Yuichi UCHIDA, Keitetsu ROKUGO and Wataru KOYANAGI
}

\begin{abstract}
The establishment of test methods for determination of the tension softening diagrams of concrete has been desired. In this contribution, following the discussions on the existing $J$-integral approaches a simple and handy test method for determination of the tension softening diagrams from bending tests on notched beams is proposed. The method has the following features : (1) the tension softening diagrams can be determined from a single beam specimen, (2) the method can be combined with the RILEM method for determination of the fracture energy $G_{F},(3)$ only the load, the loading point displacement and the crack opening at the notch tip are necessary to be measured, (4) the second derivative of the potential energy is introduced to improve the accuracy of the estimation of the diagrams. The proposed method is applied to concretes including high strength concrete and light weight concrete to determine tension softening diagrams, and the validity of the method is certified.

Keywords : tension softening, fracture mechanics, bending test, fracture energy
\end{abstract}

\section{1. まえがき}

近年, コンクリートの破壊に関するより詳細な議論や 破壊についての高精度な予測手法の確立が必要となり， 圧縮強度や引張強度などの強度特性ばかりでなく, より 多くの材料特性が数值解析に組み込める形で必要亡され ている.

ひびわれの進展によって生じるコンクリートの破壊の 特徵は，巨視的に完全に開口したひびわれの先端に微細 なひびわれが累積した破壊進行領域 (fracture process zone）とよばれる非線形領域が存在することである ${ }^{11}$. ひびわれの生じていない弾性領域と完全なひびわれ部分 との中間にあるこの破壊進行領域では，引張ひずみ(あ るいは, その領域におけるひびわれ幅の総和）の増大に 伴って, 伝達される引張応力が減少するいわゆる引張軟 化現象が生じる.

引張応力下のコンクリートの破壊エネルギー $G_{F}$ (fracture energy, 単位投影面積のひびわれの形成に必要な エネルギーであり, 引張軟化曲線下の面積) や, 引張軟

* 正会員 工修 岐皁大学助手 工学部土木工学科 ( ₹501-11 岐皁市柳戸 1-1)

** 正会員 工博 岐皁大学助教授 工学部土木工学科(同上)

*** 正会員 工博 岐阜大学教授 工学部土木工学科 (同上)
化曲線 (tension softening curve,ひびわれの成長に伴っ て減少する引張伝達応力と引張ひずみまたはひびわれ幅 との関係）などの引張軟化特性を数值解析や理論に組み 込み，ひびわれの進展によるコンクリートの破壊現象に ついて検討しようとする，いわゆるコンクリートの破壊 力学に関する研究が最近盛んになっている.このコンク リートの破壊力学の分野では, 破壊進行領域の実態把握, 脆性破壊現象や強度の寸法効果の合理的解釈, コンク リートの性能評価などへの引張軟化現象の応用に加え， 引張軟化特性の計測方法の確立が特に重要とされてい る1!.

コンクリートの破壞エネルギーを求めるための試験法 としては, 切欠きを付けたはりの 3 点曲げ試験法が RILEM から提案されている2!. 一方，コンクリートの 引張軟化曲線は直接引張試験から求めることが望ましい が，一般にコンクリートの引張試験を完全に制御し，最 大耐力点以降の荷重-変位曲線を安定に計測することは 容易でない. 引張軟化曲線を求める方法としては, 直接 引張試験法 ${ }^{3)}$, 数值解析と実験を併用する方法 ${ }^{4)}$, 多重 切断法 ${ }^{5}$ 等が提案されているが, これらは, 特殊な試験 装置, 解析プログラム, あるいは高度な技巧を要し, 設 備の整った試験機関においてさえ決して容易な試験方法 とはいえないと考えられる。 
一方, Li ら ${ }^{6}$ が提案した切欠きはりの曲げ試験から $J$ 積分を介して引張軟化曲線を求める方法, あるいはこれ を簡略化した新 $J$ 積分法 ${ }^{7}$ は精度上検討すべき点はある ものの, 試験自体は, 特殊な試験装置や計測装置を必要 とせず,比較的簡便で実用的な方法であると考えられる。

本研究は, 切欠きはりの曲げ試験から $J$ 積分值を介 して引張軟化曲線を求める試験法について検討したもの である.すなわち, Li らの $J$ 積分法やこれを改良した 著者らの新 $J$ 積分法について理論的に考察し, さらに これらを改良した修正 $J$ 積分法を提案した. また，普 通強度コンクリート, 高強度コンクリートおよび軽量コ ンクリートについて修正 $J$ 積分法により引張軟化曲線 を求めるとともに, その妥当性について数值解析結果と 試験結果をもとに検討したものである。

\section{2. 引張軟化曲線と切欠きはりの荷重-変位曲線}

コンクリート部材の巨視的なひびわれの進展過程を解 析するために, 有限要素法あるいは境界要素法に仮想ひ びわれモデルを組み込む方法がある1".これは，ひびわ れの進展を要素節点の分離でモデル化し, 分離された節 点にその節点間距離（ひびわれ開口変位）に応じて引張 軟化曲線から定まるひびわれ間の伝達力を等価節点力と して作用させるものである.この方法は一本の主ひびわ れの進展が部材の挙動を支配しているような場合に有効 であり, 特に部材の最大耐力以降のいわゆる下降域の解 析も可能である. 以下に, この方法を用いて切欠きを有 する曲げ供試体について, 引張軟化特性をパラメータ一 にとって解析した結果を示す.

図一1 には供試体の要素分割図を示す．供試体は $10 \times$ $10 \times 84 \mathrm{~cm}$ (載荷スパン $80 \mathrm{~cm}$ ) であり, スパン中央に 深さ $5 \mathrm{~cm}$ の切欠きを設けたものである. なお, この供 試体は曲げ試験から破壊エネルギーを求める RILEM の試験法で使用される供試体を想定したものである.

図一2 は仮想ひびわれの構成式として用いた引張軟化 曲線を示したものである. 引張軟化曲線のモデルとして は種々のものがある. 2 直線モデルでは折れ点の応力を 引張強度の $1 / 3$ としたモデル ${ }^{3)} 1 / 4$ としたモデル ${ }^{8)}$ どが提案されている. また，図一2 中に示したー3 乗乇 デル を含む種々の曲線モデルも提案されている.ここ では特に, 実験結果との適合が比較的よいといわれてい る $1 / 4$ モデルとー3 乗モデルをとりあげ, さらに比較の

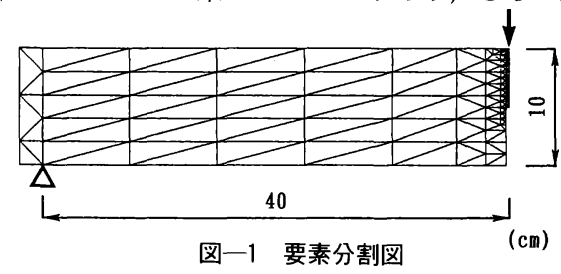

ために 1 直線モデルも用いた。

図一3 は図一1に示す供試体のスパン中央に載荷した 場合の荷重-変位曲線を, 破壊エネルギー $G_{F}$ を 0.15 $\mathrm{kgf} / \mathrm{cm}$ として図一2 の-3 乗モデルを用い, 引張強度を $20,35,50 \mathrm{kgf} / \mathrm{cm}^{2}$ 亡変化させて求めた解析結果であ る. 引張強度が増加するに従って供試体の最大耐力は増 加している. しかし, 引張強度が高くなるにつれて引張 強度に対する曲げ強度（最大曲げモーメントを切欠き断 面の断面係数で除した值）の比率は小さくなっている. 図一4はー3 乗モデルを用い引張強度を $35 \mathrm{kgf} / \mathrm{cm}^{2}$ とし
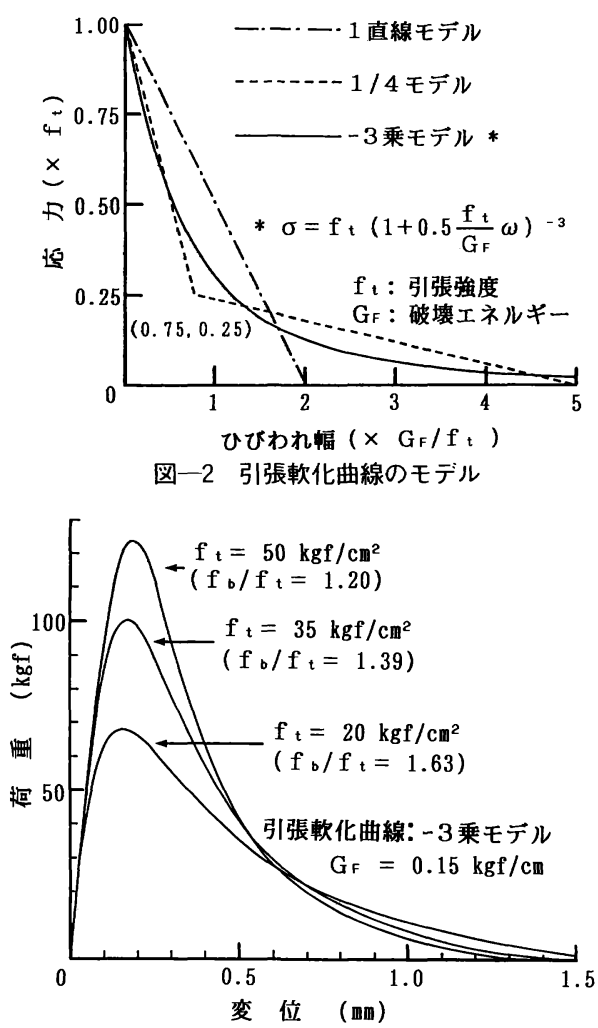

図一3 引張強度とはりの荷重-変位曲線の関係

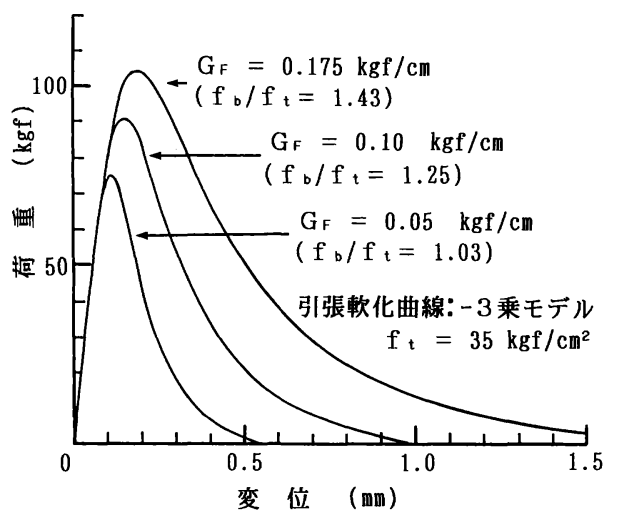

図一4＼cjkstart破壊エネルギーとはりの荷重-変位曲線の関係 
て破壊エネルギー $G_{F}$ のみを変化させた場合の荷重-変 位曲線である。 $G_{F}$ の值は, 小さい值として軽量コンク リートを想定して $0.05 \mathrm{kgf} / \mathrm{cm}$ を採用し，また大きい值 として普通コンクリートで得られる值より若干大きめの $0.175 \mathrm{kgf} / \mathrm{cm}$ を さらにそれらの中間の值として 0.10 $\mathrm{kgf} / \mathrm{cm}$ を採用した。図一4に示すとおり $G_{F}$ が大きくな るにつれて耐力が大きくなっており，コンクリートの曲 げ強度に対して破壊エネルギーが影響していることがわ かる. 図一5 は引張強度, 破壊エネルギーが等しく引張 軟化曲線の形状のみが異なる場合の結果を示したもので ある. 特に 1 直線モデルの場合は 2 直線モデルあるいは 曲線モデルの場合に比べて荷重が大きく, 荷重-変位曲 線の形状も全く異なっており, 部材の破壊挙動を推測す るうえで引張軟化曲線の形状も重要なパラメーターであ ることがわかる. なお, 2 直線モデルと曲線モデルを比 ベると最大耐力点以降に多少の差は認められるがほぼ同 一の荷重-変位曲線が得られている。したがって, モデ ル化した引張軟化曲線を用いて解析を行う場合には比較 的単純な 2 直線モデルでも十分に実験結果を追跡できる と考えられる.

以上のように, 引張り域においてひびわれを伴うコン クリート部材の挙動に対しては，コンクリートの強度ば かりでなく破壊エネルギーあるいは引張軟化曲線の形状 が影響している、したがって, 部材の破壊挙動を推測す る場合, 破壊エネルギ一, 引張軟化曲線といったコンク リートの引張軟化特性をどのように定めるか，あるいは 計測するかは重要な課題と考えられる。そこで, 以下に コンクリートの引張軟化曲線を実験的に計測する方法に ついて述べる.

\section{3. 引張軟化曲線の推定方法}

\section{（1）曲げ試験から引張軟化曲線を求める理論}

いま, 一様引張を受けるコンクリートの引張軟化曲線 が次式で表わされるとする.

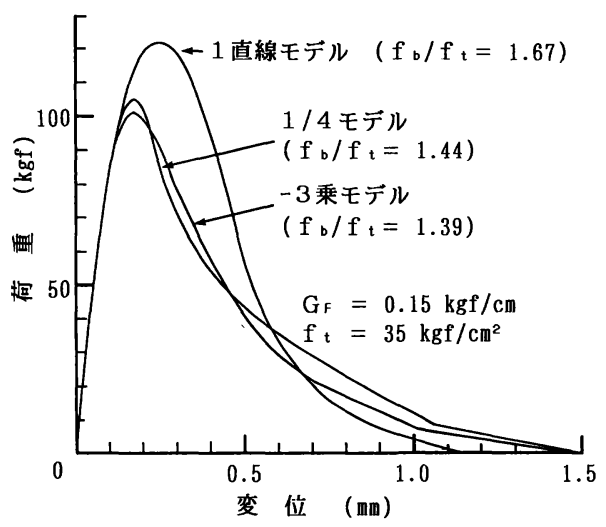

図一5 引張軟化曲線の形状とはりの荷重-変位曲線の関係 $\sigma=\sigma(\omega)$

ここに, $\sigma:$ 引張応力, $\omega:$ ひひれれ幅

単位面積当たりのひびわれが，ひびわれ幅 $\omega$ に達す るまでに必要とするエネルギー $e(\omega)$ は引張軟化曲線下 の面積で表わされるので $e(\omega)$ は次式で表わされる（図 $6)$.

$$
e(\omega)=\int_{0}^{\omega} \sigma(\omega) d \omega
$$

なお，引張応力がちょうど 0 になるときのひびわれ幅を $\omega_{c r}$ とすれば $\sigma\left(\omega_{c r}\right)=0$ であり, $e\left(\omega_{c r}\right)$ は破壊エネル ギー $G_{F}$ に一致する. 式 $(2)$ を逆に読みかえると, $e(\omega)$ が実験的に求められれば，それを微分することで $\sigma(\omega)$ が求まることになる.すなわち,

$$
\sigma=\sigma(\omega)=\frac{d e(\omega)}{d \omega} \text {. }
$$

したがって, 引張軟化曲線を求めるためには $e(\omega)$ が計 測されればよい.

いま，図一7に示すように，ひびわれの長さが $a ， ひ$ びわれ幅の分布が $\omega(y)$ の状態を考える.この状態に至 るまでにひびわれ部のみで消費されるエネルギー $E$ は， 式（2）をさらにひびわれ深さ方向に積分して

$$
\begin{aligned}
& E=b \cdot \int_{0}^{a} e(\omega(y)) d y \cdots . . \\
& \text { ここに, } b \text { : 供試体の幅. }
\end{aligned}
$$

となる。したがって，E，aおよび $\omega(y)$ がそれぞれ実 験的に計測されれば上式より $e(\omega)$ が求められ, さらに 微分して引張軟化曲線が決定される.

\section{（2） $\boldsymbol{J}$ 積 分 法}

Li ら ${ }^{6)}$ $J$ 積分法では, 図一8に示すように切欠き長
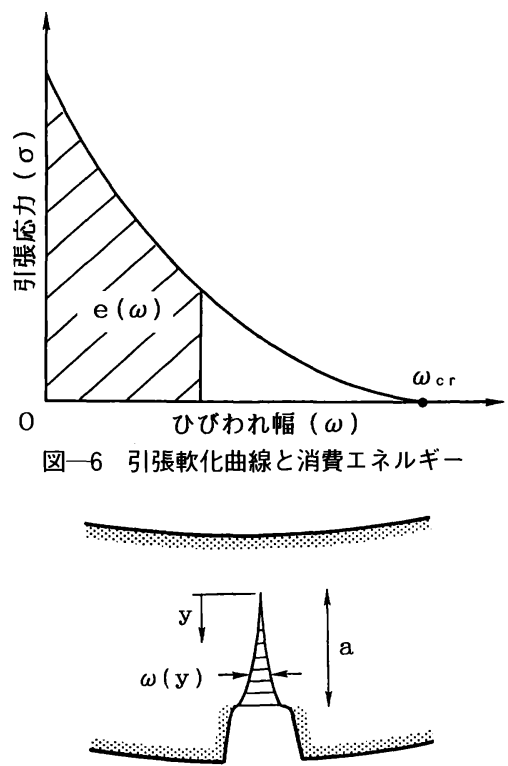

図-7 切欠き先端部 


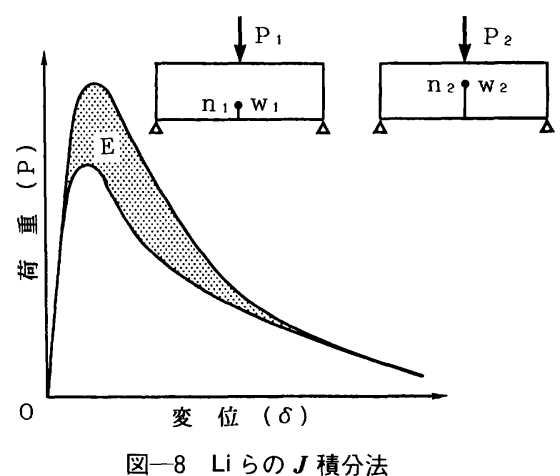

さのみがわずかに異なる 2 体の曲げ供試体（切欠き長さ $\left.n_{1}<n_{2}\right)$ について載荷試験を行い, 式 (4) 中の $E, a$, および $\omega(y)$ を計測, あるいは仮定して $e(\omega)$ を求めてい る.なお， $J$ 積分法では $e(\omega)$ を $J$ 積分値としている. $J$ 積分法で対象としているひびわれは両供試体の切欠き 長さの差の部分であり, そのひびわれ長さは $a=n_{2}-$ $n_{1}$ である. この対象とするひびわれ部で消費されるエ ネルギー $E$ は, 両供試体の荷重-変位曲線 $\left(P_{1}(\delta), P_{2}(\delta)\right)$ の面積の差として求められる.ひびわれ幅の分布につい ては，切欠き長さの差を微小にすることで，この区間で は一様分布を仅定し, ひびわれ幅 $\omega$ を両供試体の切欠 き先端の開口変位 $\left(w_{1}, w_{2}\right)$ の平均值 $\left(\omega=\left(w_{1}+w_{2}\right) / 2\right)$ としている、したがって, 式 (4) から

$$
e(\omega)=E(\omega) /(b \cdot a) \text {. }
$$

ここに, $\omega=\omega(\delta)=\left(w_{1}(\delta)+w_{2}(\delta)\right) / 2$

$$
\begin{aligned}
& E(\omega)=E(\omega(\delta))=\int_{0}^{\sigma}\left(P_{1}(\delta)-P_{2}(\delta)\right) d \delta \\
& a=n_{2}-n_{1}
\end{aligned}
$$

となり, 式 $(5)$ を微分すれば引張軟化曲線が推定され る.

$J$ 積分法を検証する目的で，有限要素法による切欠き はりの解析結果に $J$ 積分法を適用した結果, 同方法は 解析上は非常に精度がよいが, 実測值に $J$ 積分法をそ のまま適用すると，ばらつきの大きい引張軟化曲線が推 定される傾向のあることが明らかとなっている ${ }^{10}$. その 原因は式（5）に示すように， $J$ 積分法では $2 つ$ 供試 体の試験結果の差を用いるために，計測值のばらつきを 拡大して取り入れてしまう可能性があるためである。す なわち, $J$ 積分法の欠点は 1 本の引張軟化曲線を推定す るために，2 体の計測結果を必要とすることであり，こ のことが試験を繁雑にするばかりでなく，不安定な試験 結果を導く原因ともなるのである.

\section{（3）新 $\boldsymbol{J}$ 積分法}

著者らは $J$ 積分法を簡略化して, 1 体の供試体の計測 結果のみから引張軟化曲線を推定する方法を提案し
た7). すなわち, $J$ 積分法において, 2 種類の切欠きの うち 1 種類の切欠きの長さを大きくして, 供試体の上縁 まで切欠きを入れた仮想の供試体を考え, これと実際の 供試体との間に $J$ 積分法を適用しようとしたものであ る.この簡略化が, 式 (4) を解くうえでどのような操 作に対応しているかを以下に示す.

ひびわれ長さ $a$ は両供試体の切欠き長さの差である から, 実際の供試体のリガメント長さ（供試体の高さか ら切欠きの長さを引いたもの) を $a_{0}$ とすれば $a=a_{0}$ と

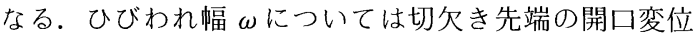
の平均値であるから, 仮想の供試体の開口変位は常に 0 であるので，実際の供試体の開口変位を $w$ とすれば $\omega$ $=w / 2$ である. また，ひびわれ部で消費されるエネル ギー $E$ は, 実際の供試体の荷重一変位曲線下の面積之な り，供試体に加えられるエネルギーはすべてひびわれ部 で消費されることになる，以上の操作により，式 (4) は次式のようになる.

$$
E(\omega)=A_{\mathrm{ig}} \cdot e(\omega) \cdot
$$

ここに, $A_{1 \mathrm{ig}}$ はりガメント面積 $\left(=b \cdot a_{0}\right)$.

一方, ひびわれ幅が $\omega に$ に達するまで, すなわち切欠 き先端の開口変位が $w(=2 \omega)$ に達するまでに供試体 に加えられるエネルギーは, 開口変位が $w$ のときの荷 重点変位を $\delta_{w}$ とすると, 荷重一変位曲線を積分して,

$$
E(\omega)=\int_{0}^{\sigma_{w}} P(\delta) d \delta
$$

であるから， $e(\omega)$ は次式で与えられる.

$$
e(\omega)=1 / A_{1 \mathrm{ig}} \cdot \int_{0}^{\delta w} P(\delta) d \delta
$$

なお, 式 $(7)$ 中の荷重-変位曲線 $P(\delta)$ には供試体の 自重による影響を補正するために，付加的な荷重として 供試体重量の半分を加えたものを用いる.

さらに，新 $J$ 積分法を簡単に表わすならば，図一9の ようになる。すななわ，新 $J$ 積分法は，はり供試体の 破壊をひびわれ幅がはり供試体の切欠き先端の開口変位 の半分でしかもひびわれ部以外は剛体である架空の一軸 引張供試体の破壊に置き換え, その両者でひびわれ部で 消費されるエネルギーが等しいとしたものである.

新 $J$ 積分法を検証するために, 切欠きはりの有限要 素法による解析結果に対して新 $J$ 積分法を適用してみ た。供試体は図一1に示したものと同様のものである. 有限要素解析で入力した引張軟化曲線は図一2 の 2 直線 モデルと曲線モデルである. 図一10,11に入力した引張 軟化曲線と新 $J$ 積分法で推定された軟化曲線を示す. 曲線モデルの場合には，ひびわれ幅が小さい領域で，入 力値に比へ応力が低く推定されている. また，2 直線モ デルの場合には, 推定された曲線は, 折れ点の座標が図 中左上方向に移動した形状になっている，さらに，いず 

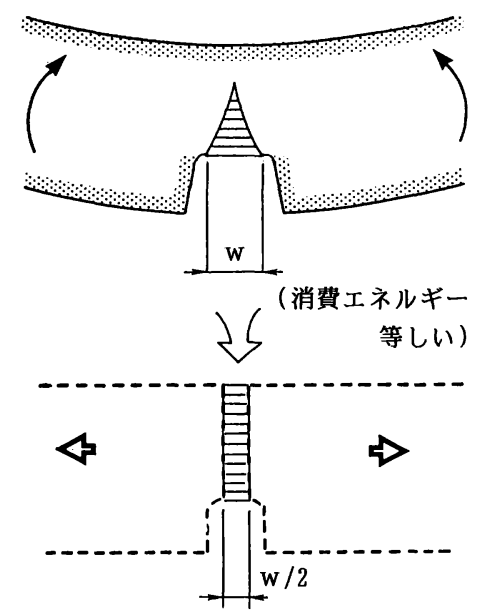

図一9 新 $J$ 積分法のモデル化

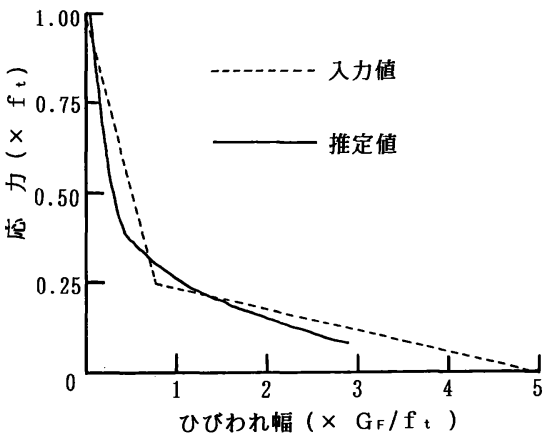

図一10 新 $\boldsymbol{J}$ 積分法による推定（2 直線モデル）

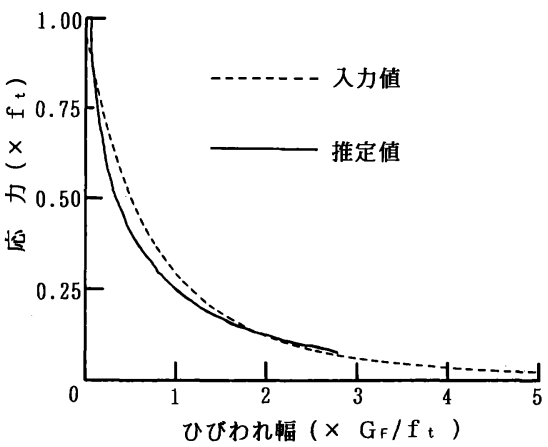

図一11 新 $\boldsymbol{J}$ 積分法による推定（曲線モデル）

れのモデルの場合でも, 引張強度は入力值と一致してい ない.これらの誤差の原因としては, リガメント内にお ける圧縮域とひびわれがまだ発生していない領域を無視 していること,ひびわれ部以外の領域で蓄えられる弾性 ひずみエネルギーを考慮していないこと, およびひびわ れ幅の分布を一様として, しかもその幅を切欠き先端の 開口変位の半分としていることが挙げられる.

しかしながら, 新 $J$ 積分法は, 実験值に適用した場
合でも $J$ 積分法に比べてばらつきの少ない安定した軟 化曲線が得られ, 軟化曲線の概略を求める場合, あるい は材料の引張軟化曲線を相対的に比較するような場合に は有効な方法と考えられる. また, 新 $J$ 積分法の試験 は破壊エネルギーを求める RILEM の試験法に準じて 行うことができるので破壊エネルギーも同時に計測する ことができる点が合理的である.

\section{（4）修正 $\boldsymbol{J}$ 積分法}

上述の新 $J$ 積分法において設けた仮定をまとめると 以下のようになる。

i ）ひびわれ長さはリガメント長さとする.

ii）供試体に加えられたエネルギーはすべてひびわれ 部でのみで消費されるとする.

iii）ひびわれ幅は切欠き先端の開口変位の半分で分布 は一様とする。

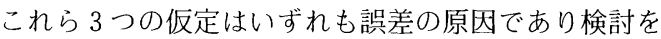
要する事項である.ここで，推定精度の向上を目的とし て, 新 $J$ 積分法を一部修正した修正 $J$ 積分法を提案す る.修正に際して上記 3 つの仮定について検討した結果， i ）と ii ) については修正せず，iii）のみを修正するこ ととした.すなわち，ひびわれ長さを奏験的に検出する こと，および弾性ひずみエネルギーだけを加力エネル ギ一から分離して求めることは, 特殊な計測装置あるい は繰返し載荷のような繁雑な操作を要することになり， 試験の実用性を考えた場合, 現状では困難であると判断 し， i ）と ii ）の仮定については変更しないものとした。 一方，iii）については，新 $J$ 積分法では図一9に示した ように曲げ変形のモードを一軸引張のモードにモデル化 したのに対して, 修正 $J$ 積分法では図一12 に示すよう に変形モードを切欠き真上の供試体縁を回転中心とした 剛体回転とすることで，より実際に近いモードを採用す ることとした.このことにより，新 $J$ 積分法において は引張軟化曲線のひびわれ幅が曲げ供試体の切欠き先端 の開口変位の半分と結び付けられていたため, その物理 的意味があいまいであったが, 修正 $J$ 積分法により軟 化曲線のひびわれ幅は切欠き先端の開口変位と直接的に 結び付けられることになる.

図一12において，切欠き先端の開口変位が $w$ に達す るまでにひびわれ部で消費されるエネルギー $E$ は，式 (4) において $\omega(y)=w / a_{0} \cdot y$ として

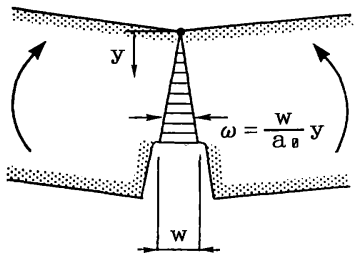

図一12 修正 $J$ 積分法のモデル化 


$$
E(w)=\frac{A_{1 \mathrm{ig}}}{w} \int_{0}^{w} e(w) d w
$$

上式の両辺を $w$ で 2 階微分して, 式 (3) の関係を用 いると次式が得られる.

$$
\sigma(w)=\left(w E^{\prime \prime}(w)+2 E^{\prime}(w)\right) / A_{\mathbf{l i g}}
$$

一方, $E(w)$ は新 $J$ 積分法の場合と同様, 供試体の加力 エネルギーに等しいとして, 切欠き先端の開口変位が $w$ のときの荷重点変位を $\delta_{w}$ とすれば，荷重-変位曲線 を積分して次式のように与えられる.

$$
E(w)=\int_{0}^{o w} P(\delta) d \delta
$$

以上, 式 $(10)$ と式 $(11)$ より $\sigma(w)$ を求め, $w$ を $\omega$ に読み変えれば引張軟化曲線が得られる。なお，式 (11) 中の荷重-変位曲線 $P(\delta)$ は供試体の自重による影響を 補正するために，付加的な荷重として供試体重量の半分 を加えたものを用いる.

図一13，14には，それぞれ図一2 の 2 直線モデルと曲 線モデルを入力した有限要素法による解析結果に対して 修正 $J$ 積分法を適用した結果を示す。いずれのモデル の場合でも修正 $J$ 積分法で推定された軟化曲線の形状 は, 入力した曲線によく一致しており, 図一10,11 に示 した新 $J$ 積分法に比べより精度が高いことがわかる. しかし，修正 $J$ 積分法の場合でも引張強度は推定でき ていない. 引張強度を推定できないのは, 引張強度が推

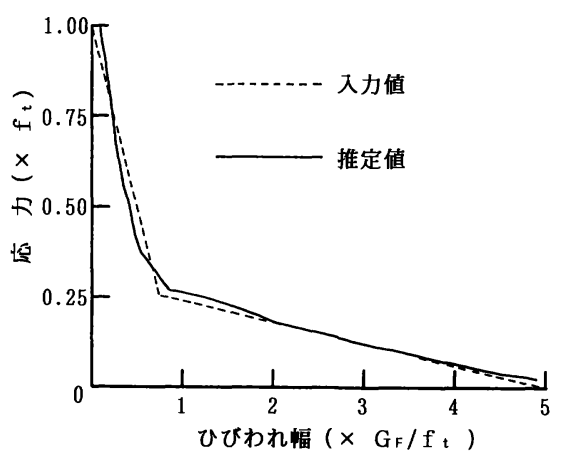

図一13 修正 $\boldsymbol{J}$ 積分法による推定（2 直線モデル）

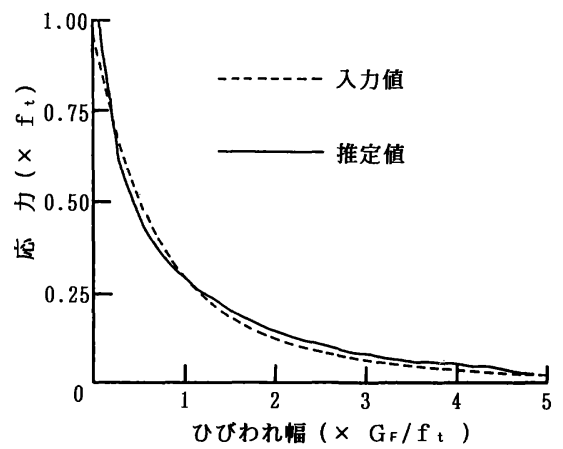

図一14 修正 $\boldsymbol{J}$ 積分法による推定（曲線モデル）
定される載荷のごく初期の段階においても，ひびわれ長 さをリガメント長さに等しいとしていること，およびひ びわれ部以外の領域で蓄えられる弾性ひずみエネルギー の影響を無視してしまうことが主な原因と考えられる。 また, 式 $(10)$ には $E(w)$ の 1 階微分と 2 階微分が含ま れているため, 数値微分をする際に滑らかな微分值が得 られるようにしないと推定される曲線が乱れることにな る. 特に, 引張強度点付近では $E(w)$ の絶対值が小さく, 解析誤差 (実験では計測誤差) の影響を受けやすく曲線 が乱れる傾向が強い.したがって, 修正 $J$ 積分法で引 張軟化曲線を推定する場合でも, 引張強度点については 別途，引張強度試験を行い修正する必要があると考えら れる，具体的な修正方法については，次章で述べる。

なお，ひびわれ長さの仮定と弾性ひずみエネルギーを 無視するという大きな仮定を設けても，曲線の概形の推 定ができるのは以下の理由によるものと考えられる.す なわち，初期の段階においてひびわれ長さを実際のひび われより長く評価することは，実際のひびわれが消費す るエネルギー $e(\omega)$ を過小評価することになり，一方， 弾性ひずみエネルギーを無視することは $e(\omega)$ を過大評 価することになり，この両者がある程度相殺するためと 考えられる. 図一15 は有限要素解析（普通コンクリー 卜を想定した図一 3 の $f_{t}=35 \mathrm{kgf} / \mathrm{cm}^{2}$ のもの) において 得られた切欠き先端の開口変位を横軸により，そのとき のリガメント長さに対するひびわれ長さ $\left(a / a_{0}\right)$ とひび われ部で消費されたエネルギーに対する全加力エネル ギー $\left(E_{T} / E_{F}\right)$ を示したものである.ここで， $a / a_{0}$ はひ びわれ長さを $a_{0}$ と仮定することによる $e(\omega)$ の過小評価 分を表わし， $E_{T} / E_{F}$ は弾性ひずみエネルギーを無視す ることによる過大評価分を表わしており，それらの積 $\left(a / a_{0}\right) \cdot\left(E_{T} / E_{F}\right)$ は最終的に評価される $e(\omega)$ の真の值に 対する割合を表わしていると考えられる. 同図に示すと おり $\left(a / a_{0}\right) \cdot\left(E_{\tau} / E_{F}\right)$ は，ひびわれ幅の小さい初期の段 階でわずかに差があるものの, 最大耐力点付近以降はほ

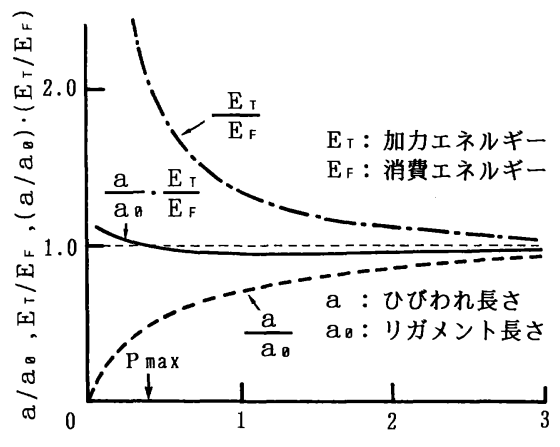

開口変位 $\left(\times G_{F} / f_{t}\right)$

図一15 $e(\omega)$ に対するひびわれ長さと弾性ひずみ エネルギーの影響 
ぼ 1.0 になっており，2つの仮定による誤差がちょうど 相殺されていることがわかる。

\section{4. 各種コンクリートの引張軟化特性の計測}

\section{（1）実 験 概 要}

高強度コンクリート，軽量コンクリートおよび載荷材 令の異なる普通強度コンクリートについて, 修正 $J$ 積 分法による引張軟化曲線の推定を行った，また，試験は 破壊エネルギーを求めるための RILEM の試験法”にに準 じて行い， $G_{F}$ の計測も同時に行った. 高強度コンクリー 卜は水セメント比を $27 \%$ として, 高性能減水剂を用い て作成した。軽量コンクリートは細骨材，粗骨材（造粒 型）ともに軽量骨材を使用し，単位容積重量は $1.63 \mathrm{t} /$ $\mathrm{m}^{3}$ である，普通強度コンクリートについては，材令の 異なる 3 日，7日，28 日で試験を行った。

試験装置を図一16に示す。試験機には容量 $200 \mathrm{tf} の$ 耐圧試験機を用いた。この試験機はサーボコントロー ラ一等の変位制御装置の付いていない通常のアムスラー 型耐圧試験機である。両支点下にはローラーを配置して 水平方向の拘束をできる限り取り除くようにした. 載荷 点変位は供試体底面の切欠きをはさんだ 2 点で高感度変 位計（感度 $1 / 1000 \mathrm{~mm}$ ) を用いて計測しその平均值と した. 切欠き先端の開口変位は高感度変位計 (感度 1 / $2000 \mathrm{~mm}$ ) を供試体側面に直接取り付けて計測した。 なお, 開口変位を計測する際，検長は $3.0 \mathrm{~cm} と し ，$ 検 長内に含まれる弾性変形分はひびわれ幅に比較して十分 小さいので無視することとした．供試体寸法は，10×10 $\times 84 \mathrm{~cm}$ (載荷スパン $80 \mathrm{~cm}$ ), 切欠き深さ $5.0 \mathrm{~cm}$ である. 高強度ならびに軽量コンクリートについては, 打設後 2 週間の湿布養生を行い, その後約 8 週間気中養生を行っ た. 普通強度コンクリートについては湿布養生とした。 各供試体とも試験前日にコンクリートカッターによって 切欠きを加工した．切欠きの幅は，切欠き先端を含め全 長にわたって約 $5 \mathrm{~mm}$ である. 供試体の数は 1 条件につ き 5 ないし 6 本とした. 載荷速度は 30 秒から 60 秒程度 で最大荷重に達するようにした，最大耐力点以降，破壊 が急激に進展するような場合には，除荷，載荷を繰り返 し，不安定破壊が生じないように制御した。

\section{(2) 実験結果と考察}

試験結果の一覧を表一1 に示す．各コンクリートの荷

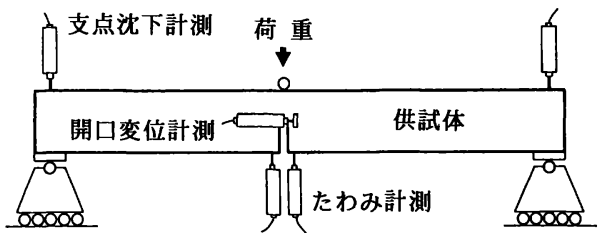

図一16 3 点曲げ試験
表一1 コンクリートの力学特性

\begin{tabular}{|c|c|c|c|c|}
\hline \multirow{2}{*}{$\begin{array}{l}コ ン ク \\
\text { リート }\end{array}$} & \multicolumn{3}{|c|}{ 度 $\left(\mathrm{kgf} / \mathrm{cm}^{2}\right)$} & \multirow{2}{*}{$\begin{array}{c}G \mathrm{G} \\
(\mathrm{kgf} / \mathrm{cm})\end{array}$} \\
\hline & 圧 & 引 & 曲 げ & \\
\hline 高強度 & 848 & 53.0 & 75.7 & 0.178 \\
\hline 軽 & 344 & 22.3 & 30.1 & 0.053 \\
\hline 普通 3 日 & 195 & 17.6 & 38.2 & 0.134 \\
\hline 普通 7 日 & 292 & 26.7 & 46.6 & 0.144 \\
\hline 普通28日 & 407 & 34.3 & 50.5 & 0.160 \\
\hline
\end{tabular}

*曲 げ強度は載荷試験後の供試体片 $(10 \times 10 \times 42 \mathrm{~cm})$ を使用した。引張強度は割裂引張強度である。

重-変位曲線を図一17〜図一21に示す.なお，荷重-変 位曲線は特に最大耐力点以降ばらつきが大きいので，全 供試体の曲線群を包絡する範囲を影を付けて示した．高 強度コンクリートでは，普通強度コンクリートに比ベ， 圧縮強度や引張強度の増加ほどには破壊エネルギーは増 加していない。また，軽量コンクリートでは破壊エネル ギーが普通強度コンクリートの $1 / 3$ 程度になった。普通 強度コンクリートについて，材令に伴う強度の変化をみ ると, 圧縮強度と引張強度の増加に比べ，曲げ強度はそ

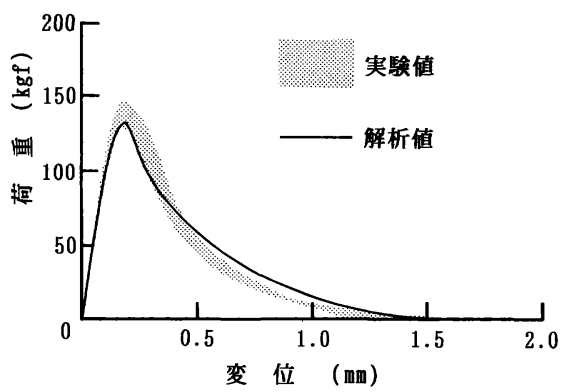

図-17 高強度コンクリートの荷重-変位曲線

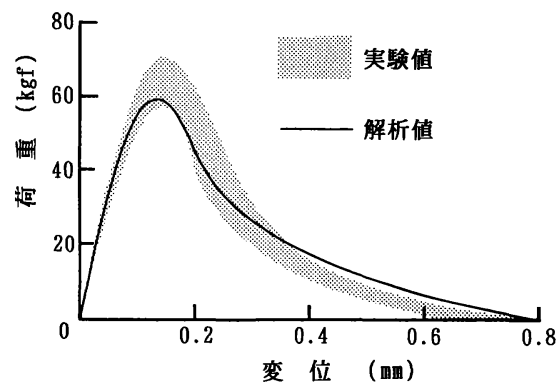

図一18＼cjkstart軽量コンクリートの荷重-変位曲線

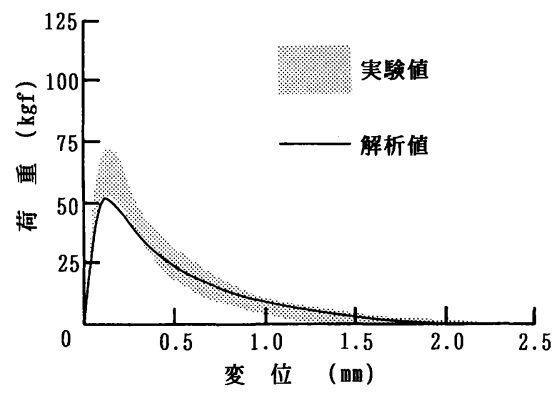

図一19材令 3 日の荷重-变位曲線 


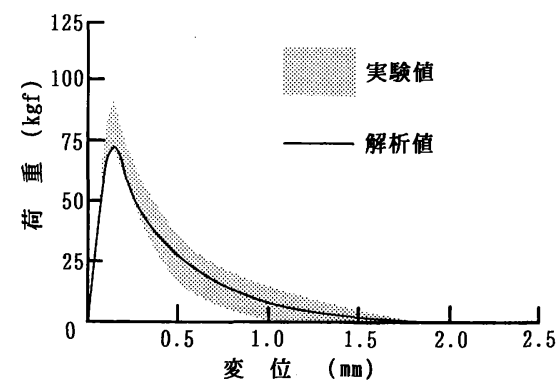

図一20 材令 7 日の荷重-変位曲線

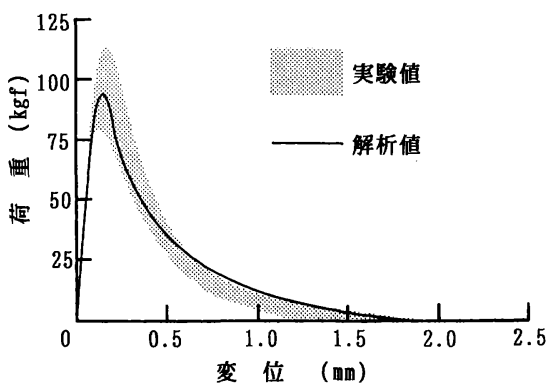

図一21材令 28 日の荷重-变位曲線

れほよ゙増加していない。これは，材令が経過しても破壊 エネルギーはそれほど増加せず，また，後述するように 引張軟化曲線の形状もほとんど変化しないためと考えら れる。

図一22には，普通コンクリートの材令 28 日のものに ついて修正 $J$ 積分法によって推定された引張軟化曲線 を示す。同図に示すとおり，実際に推定された引張軟化 曲線は引張強度点が別途行われた割裂引張強度試験の結 果とは異なっており，しかも曲線の頂点は応力軸上から はずれている，そこで，本研究では，軟化曲線の引張強 度点を割裂引張強度に置換するとともに, 割裂引張強度 点から推定された曲線に対して接線を引くことによっ て, 引張強度点付近の補正をすることとした。 なお，こ のような補正を行う理由の 1 つは, 引張軟化曲線を組み 込んで部材の解析を行う場合, 曲線形状のわずかな違い よりも, 引張強度点 (軟化開始点) をいくらにするかが 解析結果に大きな影響を与えるためである。

図一23〜図一27には各コンクリートの平均の荷重-変 位-開口変位関係を用いて修正 $J$ 積分法によって推定さ れた引張軟化曲線を実線で示す。さらに図一22に示し たのと同様の方法で引張強度点を補正したものを点線で 示す.

図一28には各コンクリートの引張軟化曲線を無次元 化したものを示す．いずれの軟化曲線もほぼ同じ形状を していることがわかる。また，同図には曲線モデルおよ び 2 直線モデルを併記してあり，いずれのコンクリート
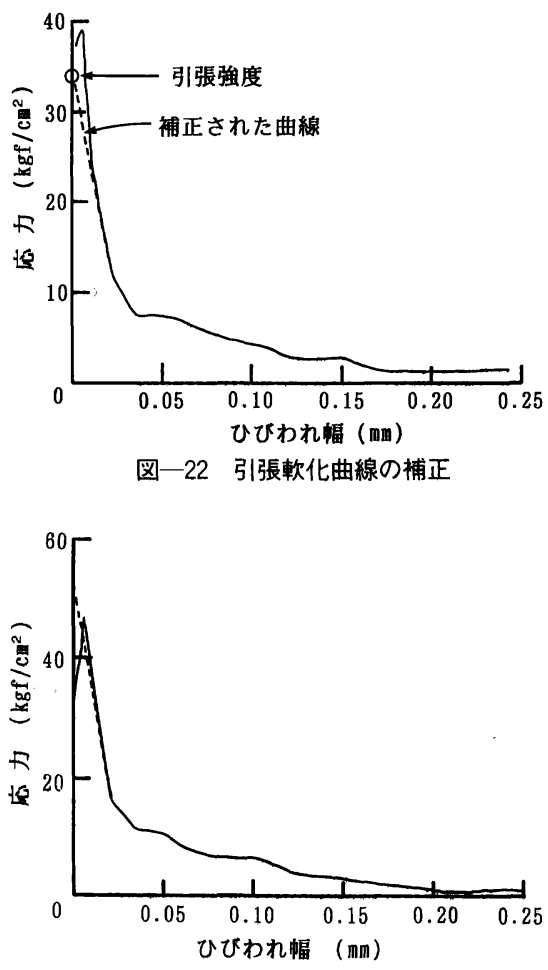

図一23 高強度コンクリートの引張軟化曲線

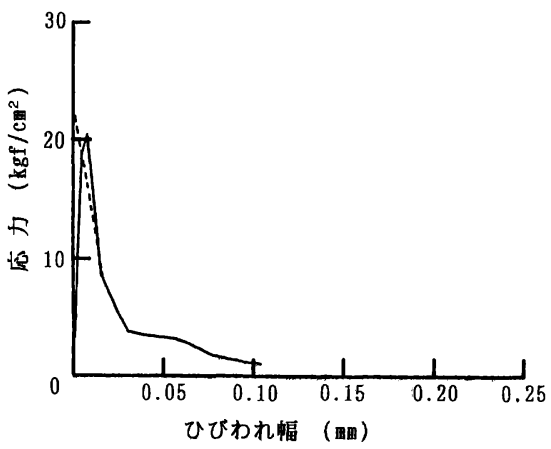

図一24軽量コンクリートの引張軟化曲線

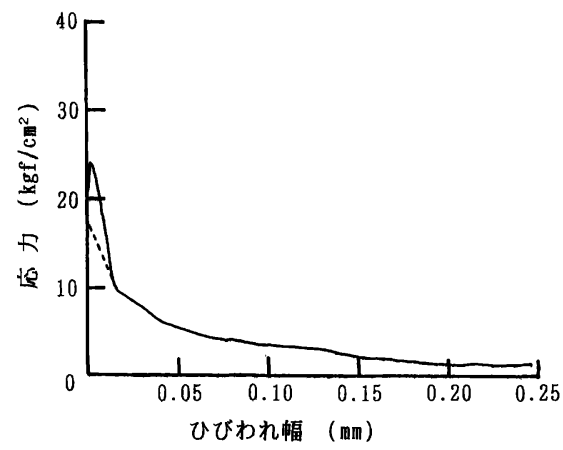

図一25 材令 3 日の引張軟化曲線 

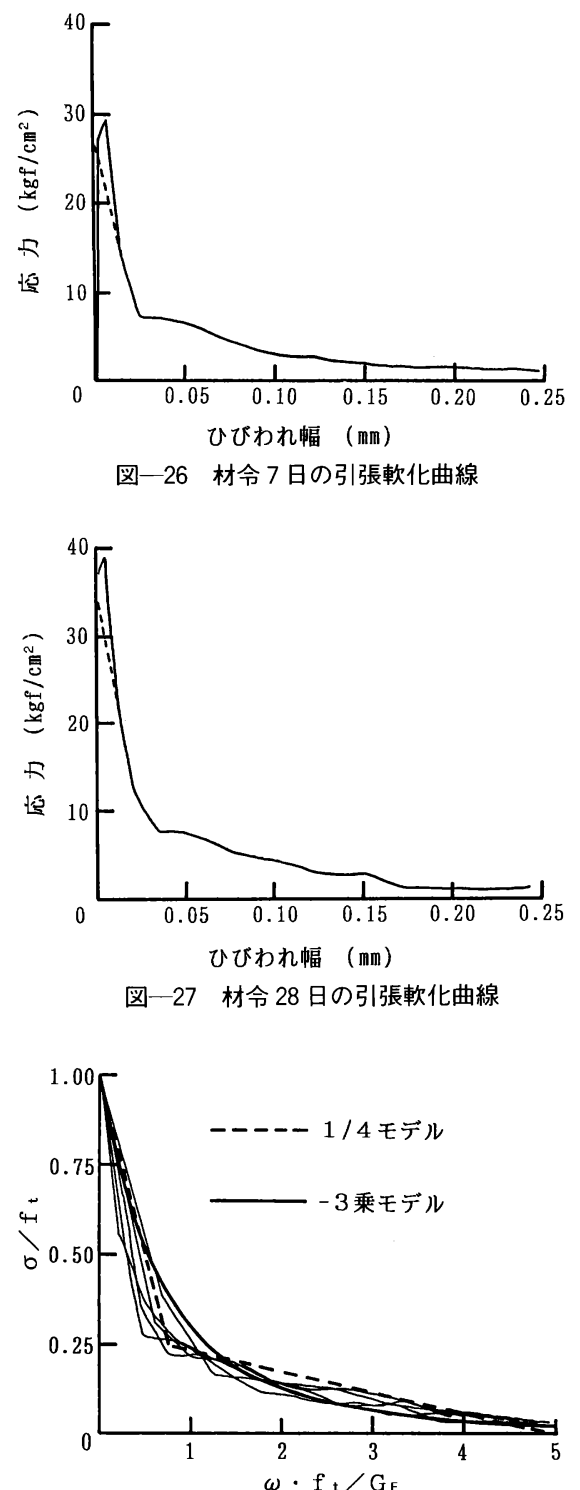

図一28 無次元化した引張軟化曲線

の場合もほぼこれらのモデルに一致していることがわか る.

前掲の図一17～図一21 には修正 $J$ 積分法によって推 定された引張軟化曲線を用いて解析した荷重-変位曲線 を実線で示した。解析では, 推定された引張軟化曲線を 4〜7 本の折れ線でモデル化したものを用いた．また， 引張軟化曲線下の面積を RILEM の方法によって求め られた破壊エネルギーに一致させるために限界ひびわれ 幅（応力が0になるひびわれ幅）を調整した．さらに， 実験では弾性係数を計測していなかったため, 解析にお いては荷重-変位曲線の初期勾配が一致するように弾性 係数を定めた. 解析の結果, 推定された引張軟化曲線を
用いることにより，いずれのコンクリートにおいても比 較的よく実験結果を追跡できている．したがって，修正 $J$ 積分法によって推定された軟化曲線は，いずれもほほ 正しいものであり，本方法によって曲げ試験からコンク リートの引張軟化曲線を精度よく推定できることが明ら かとなった。

\section{5. 結 論}

本研究では,まず,ひびわれを伴う引張域のコンクリー 卜の破壊挙動に対して, 強度特性ばかりでなく, 引張軟 化特性が影響していることを示し, 引張軟化特性を計測 することの重要性を示した。つづいて，曲げ試験から引 張軟化曲線を推定する方法としてすでに提案されている $J$ 積分法ならびに新 $J$ 積分法について理論的に考察し, それらの方法の問題点を指摘するとともに，新 $J$ 積分 法を改良して修正 $J$ 積分法を提案した. 修正 $J$ 積分法 の特色は以下のとおりである.

（1） $J$ 積分法は 1 本の引張軟化曲線を推定するため に2 体の供試体の試験結果を必要としたが, 修正 $J$ 積 分法では 1 体のみの試験結果から引張軟化曲線を推定す ることができる。

（2）修正 $J$ 積分法の試験は，切欠きはりの 3 点曲 げ試験において荷重, 荷重点変位および切欠き先端の開 口変位のみを計測すればよい。

（3）修正 $J$ 積分法の試験は，破壊エネルギ一を求 めるための RILEM の試験法と組み合わせて行うこと ができ, 引張軟化曲線と破壊エネルギーを同時に求める ことが可能である.

（4）修正 $J$ 積分法は，ポテンシャルエネルギーの 2 階微分を含んだ式によって引張軟化曲線を推定するも ので, その推定精度は新 $J$ 積分法より高い.

さらに，修正 $J$ 積分法を高強度コンクリート，軽量 コンクリートならびに普通強度コンクリートに対して実 際に適用してみた. その結果, 以下のような知見を得た.

（1）修正 $J$ 積分法によって推定された引張軟化曲 線を用いて供試体の荷重-変位曲線を解析したところ, 実験値と解析值がほぼ一致した。したがって, 修正 $J$ 積分法によってコンクリートの引張軟化曲線を精度よく 推定できると考える.

（2）本実験では 3 日，7日，28日と材令の経過に伴 う曲げ強度の増加は圧縮強度や引張強度の増加に比べて 小さくなっている。これは，曲げ強度に大きな影響を及 ぼす破壊エネルギーが材令を経てもそれほど増加せず， 引張軟化曲線の形状もほとんど変化しないためである.

（3）高強度コンクリート, 軽量コンクリートおよび 材令の異なる普通強度コンクリートの引張軟化曲線は, いずれも，1/4 モデルあるいはー3 乗モデルにほぼ一致 
している.

最後に，本研究では限られた寸法の供試体の実験結果 と解析結果しか扱っておらず，いわゆる寸法効果につい ては検討していない, したがって, 引張軟化曲線自体に 寸法効果が存在するのかどうか, 存在するのであるなら ばその程度はいくらくらいであるのか, さらにはそのメ カニズムが何であるのかといった問題については今後の 課題としたい.

\section{参 考 文 献}

1) コンクリートの破壊力学研究委員会：コンクリート構造 の破壊力学に関するコロキウム，第 1 部・委員会報告, 日本コンクリート工学協会, JCI-C 19, 1990 年 3 月.

2) RILEM Draft Recommendation (50-FMC) : Determination of the Fracture Energy of Mortar and Concrete by Means of Three-point Bend Tests on Notched Beams. Materials and Structures, Vol. 18, No.93, pp. 285 290, 1983.

3) Petersson, P.E. : Crack Growth and Development of Fracture Zone in Plain Concrete and Similar Materials, Report TVBM-1001, Division of Building Materials, Lund Institute of Technology, Sweden, 1981.

4) Wittmann, F.H., Rokugo, K., Bruhwiler, E., Mihashi, H. and Simonin, P. : Fracture Energy and Strain Softening of Concrete as Determined by means of
Compact Tension Specimens, Materials and Structures, Vol. 21, No. 121, pp. 21 32, 1988.

5) Hu, X. Z. and Wittmann, F. H. : Fracture Process Zone and $K_{r}$-curve of Hardened Cement Paste and Mortar, Fracture of Concrete and Rock, Elsevier Applied Science, pp. 307 316, 1989.

6) Li, V.C. and Ward, R. J. : A Novel Testing Technique for Post-peak Tensile Behavior of Cementitious Materials, Fracture Toughness and Fracture Energy, Balkema, pp. 183 195, 1989.

7）六郷恵哲・岩佐正徳・瀬古繁喜・小柳 洽： $J$ 積分法を 用いたコンクリートの引張軟化曲線の定量化, セメント・ コンクリート論文集，No. 43，pp. 304〜309， 1989.

8) Rokugo, K., Iwasa, M., Suzuki, T. and Koyanagi, W. : Testing Methods to Determine Tensile Strain Softening Curve and Fracture Energy of Concrete, Fracture Toughness and Fracture Energy, Balkema, pp. 153 $163,1989$.

9) Hillerborg, A. : Stability Problems in Fracture Mecha nics Testing, Fracture of Concrete and Rock, Elsevier Applied Science, pp. 369 378, 1989.

10）内田裕市・鈴木泰生・六郷恵哲・小柳 洽：曲げ武験に よるコンクリートの引張軟化曲線の計測, コンクリート 構造の破壊力学に関するコロキウム, 第 2 部・論文集, 日本コンクリート工学協会, JCI-C 19, pp. 5〜12, 1990 年 3 月.

（1990.8.20 • 受付） 